\title{
The Implementation of Zoom Cloud Meeting on Choir Learning in the Covid-19 Pandemic
}

\author{
Lukas Gunawan Arga Rakasiwi ${ }^{1 *}$, Anik Ghufron ${ }^{2}$ \\ 1,2 Graduate Program of Instructional Technology, Universitas Negeri Yogyakarta \\ Email: ${ }^{1}$ lukasgunawan.2017@student.uny.ac.id, ${ }^{2}$ anikghufron@uny.ac.id
}

\begin{abstract}
This research based of the COVID-19 pandemic which makes choir activities must change the direct learning system into online learning. This study aims to describe online choir learning using Zoom Cloud Meeting based on the learning strategies and find out the role of Zoom Cloud Meeting on the self-regulated in choir learning at Swara Wadhana Universitas Negeri Yogyakarta Student Choir. The research subjects were 30 members of the Swara Wadhana Univeritas Negeri Yogyakarta Student Choir. This study uses a qualitative approach with qualitative descriptive research methods. Collecting data using interview techniques, observation, and documentation. Data analysis using an interactive model from Miles \& Huberman which includes the steps: data reduction, data presentation, and drawing conclusions. The description of choir learning is obtained from the learning strategy: pre instructional activities, the material presentation, student participation, tests and follow-up. The indicators of self-regulated learning used in the study are independence of others, self-confidence, disciplined, responsibility, initiative, and self-control. The results showed that the cloud meeting zoom can be used as a medium for implementing choir learning in the pandemic era with the adjustment of learning strategies by the trainer; and can support self-regulated learning. The implication of this research show that independence of other-indicator can be considered and be further investigated in the online choir learning.
\end{abstract}

Keywords: Online learning, Choir learning, Self-regulated Learning, Zoom Cloud Meeting

\section{INTRODUCTION}

Several people have observed a pandemic that has recently endangered the world. Observations are carried out in very difficult stages because the opponent to be faced is an invisible virus, the virus is the COVID19/coronavirus [1]. Initially this virus was detected in Wuhan Province, China, now it is spreading rapidly around the world. The Indonesian government has issued various policies to reduce the level of the spread of the corona virus by imposing social distancing, physical distancing to the enactment of PSBB (large-scale social restrictions) in several areas. The policies issued to limit the spread of COVID-19 have an impact on various fields throughout the world, especially education in Indonesia [2]. The digitization of the teaching and learning process has accelerated rapidly as the COVID-19 pandemic has caused a sudden crisis in the world. The spread of the virus can be slowed down by flattening the "growth curve", social distancing, and working from home is a new rule that the majority of countries in the world must adhere to strictly [3].
The COVID-19 outbreak urges distance education testing that has never been carried out simultaneously before for all elements of education, students, teachers, and parents [4]. So that the distance learning system becomes a solution to overcome difficulties in implementing face-to-face learning. All elements and levels of education are challenged to keep classrooms active even though schools have closed. Online learning is effective for implementing learning even though educators and students are in different places [5]. Choir learning is also one of the lessons that have been impacted by covid-19.

In Washington State, USA, Hamner reported that the COVID-19 outbreak was spreading among church choir members. The transmission in this report occurred during 2.5 hours of choir practice, which was attended by 61 participants. Symptomatic cases accounted for 32 confirmed cases and 20 possible secondary cases, resulting in a secondary attack rate of $53.3 \%$ (confirmed cases only) to $86.7 \%$ (confirmed and probable cases). The authors concluded that a number of factors could contribute to transmission, including close proximity (6- 
10 inches for a portion of the time) for extended periods (2.5 hours), touching common surfaces (for example, stacking chairs, sharing snacks), and possibly facilitated by the act of singing [6]. The results show that the main mode of transmission of COVID-19 is through direct contact and respiratory droplets that have the potential to be pushed over a wide range of distances (Centers for Disease Control and Prevention (CDC), European Center for Disease Prevention and Control (ECDC) [7]. Respiratory droplets measured up to 2 meters from the source, and as suggested in one of these studies, the maximum transmission distance of the SARS-CoV-2 aerosol may be up to 4 meters [8] .A study assessing the horizontal distance traveled by respiratory droplets found it $=$ droplets can conduct traveling more than 2 meters and some studies have found that they travel up to 8 meters [9] Based on these data, one way to prevent the transmission of covid-19 in choirs is social distancing. However, to make the minimum distance between people it is necessary an wider place to make a rehearsal or choir learning as well. Another thing that can be done besides maintaining distance is doing online learning. Swara Wadhana UNY student choir is one of the choirs that choose online learning as a solution during this pandemic.

One of the technologies that can facilitate online choir learning is through teleconferences, for example Zoom Cloud Meeting and Google Meetings. The innovative technology of Zoom Cloud Meeting allows all participants to see and hear any classmate or lecturers and discuss using any device, including tablets, iPhones, and computers [10]. Zoom easily connects across room systems, mobile devices, and desktops to unify various campus and student sites at various distances [11]. Zoom video conferences is not only make possibility to seeing and listening, but also facilitate written and oral interactions between lecturers and students or fellow students [12]. Zoom Cloud Meeting application can facilitate users wherever they are, so distance is not a problem. This application can make a distance learning in a choir learning.

Using studies found on Nosignificantdifference.org as indicators of the effectiveness of distance and online learning, Nguyen observes that approximately $92 \%$ of all distance and online education studies find that distance and online education are at least as effective, if not better, than traditional education. [13]. In the field of music, according to students' experience, the greatest benefit of e-learning was achieved by those who already had a musical background prior to this study. The use of information and communication technology can improve students' attitudes towards self-regulated learning in terms of their music skills [14].

Self-regulated learning is one of the learning strategies in an education level which is carried out independently outside of face-to-face learning or tutorials. Self-regulated learning is a learning process carried out by students both within the school and outside the school by reading, studying and understanding knowledge in accordance with the related subject matter. Self-regulated learning is carried out by students both individually and in groups through the context of the dimensions of sources both from multimedia such as newspapers, internet, television and social communities that are in accordance with the subject matter in schools [15]. Several studies on teacher and student perceptions of self-regulated learning in post-compulsory education have been conducted [16-18]. For the different levels, all showed relatively positive results: students were open to, and could respond well to, the concept of self-study in education. However, there is also agreement on the issues that interfere with learning which have been discussed above. Teachers and students often find it difficult to find meaningful definitions or understandings. In addition, the development of self-regulated learning requires explicit clarification from the start and does not always go smoothly.

Member of Swara Wadhana Yogyakarta State University student choir whose their age is included in the adult category. Knowles formulated the principle of andragogy based on his belief that adults learn differently from children in several ways. According to him, selfregulated learning is a "process in which individuals take the initiative, with or without the help of others, in diagnosing their learning needs, formulating learning objectives, identifying human resources and materials for learning, selecting and implementing appropriate learning strategies, and evaluating learning outcomes" [19]. Students who have a high level of self-efficacy show a high degree of independence too. Each individual must have self-regulated learning, especially those who attend tertiary education [20]. According to Muhammad Nur Syam, there are two factors that affect self-regulated learning, namely internal factors and external factors. Internal factors with indicators of growing self-regulated learning that are reflected in the phenomena include: a. Responsible attitude to carry out what is entrusted and assigned $b$. Awareness of the rights and obligations of students in moral discipline, namely character that becomes behavior c. Maturity from self-concept, motivation to the development of thoughts, intentions, creations and works (gradually) d. Consciousness develops health and strength in body, spirit with healthy food, cleanliness and exercise e. Self-discipline by obeying the prevailing rules and regulations, being aware of rights and obligations, traffic safety, respecting others, and carrying out obligations [21]. Based on a study of various theories about self-regulated learning, Hidayati and Listyani formulated indicators of student learning independence as follows: (a) Independence of others, (b) Having self-confidence, (c) Behaving discipline, (d) Having a sense of responsibility, (e) Behave based on own initiative, and (f) Exercise self-control [22]. 
Explanation of choir learning using Zoom Cloud Meeting during a pandemic has an important function in the development of learning in the choir. This study aims to describe online choir learning using Zoom Cloud Meeting and to find out the role of Zoom Cloud Meeting on self-regulated in choir learning amid the Covid-19 pandemic. These results are important to help provide an overview of the online choir learning that choirs need to continue learning in the midst of a pandemic.

\section{METHODOLOGY}

This research is a type of quantitative research. The research method uses descriptive qualitative which aims to describe the role of Zoom Cloud Meeting in choir learning on self-regulated learning. The analysis is focused on learning strategies and self-regulated. The research was conducted on the choach and 30 student members of Swara Wadhana Yogyakarta State University student choir who carried out learning through Zoom Cloud Meeting with the ultimate goal of participating in the virtual choir competition. The 30 students consisted of 10 sopranos, 9 alto, 6 tenors, and 5 basses who had different majors. The subjects in this study act as informants.

The data analyzed were primary data and secondary data. Primary data is data that is obtained directly through interviews and observations of research subjects. Meanwhile, secondary data is data taken indirectly by researchers using the documentation method of books, archives, or other documents that support the objectives of this study [23]. The indicators used to describe the choir learning strategy include: pre instructional activities, material presentation, student participation, tests, follow-up activities. Meanwhile, the indicators that will be used in seeing self-regulated learning are independence, self-confidence, disciplined behavior, responsibility, self-initiative behavior, and self-control.

The analysis was carried out on the data obtained using the steps in the Miles and Huberman model, namely reducing the data according to the determination, presenting research data, and drawing conclusions that could describe the results of this study. The data taken at the time of the research will be reduced according to the needs of this study. Not all data will be used, but the data processed is data related to this research. Furthermore, the data will be explained in a descriptive narrative to reveal a description of choir learning using Zoom Cloud Meeting and the role of Zoom Cloud Meeting on selfregulated learning at Swara Wadhana Yogyakarta State University student choir. The data during the research needs to be checked again in order to be reliable and to avoid mistakes that might occur with a credibility test, which in this study will use the triangulation technique. After an in-depth study, a conclusion will be drawn to describe the role of Zoom Cloud Meeting in choir learning on the self-regulated learning of Swara Wadhana Yogyakarta State University student choir.

\section{RESULT}

The results of research regarding the role of Zoom Cloud Meeting in choir learning on student independence based on learning strategy variables and learning independence.

\subsection{Learning Strategy}

Swara Wadhana Yogyakarta State University Student Choir is a choir consisting of students with different majors backgrounds. At the time of the research, the choir was preparing to take part in the World Virtual Choir Competition. From the results of the interview, it was found that the students who took part in this competition were the result of the selection of all members of the choir, so that there were 40 people.

The learning strategy is very important for the implementation of a choir learning. In learning there are also parts that are interrelated with one another. The components in the learning strategy are the delivery of preliminary information, the delivery of information / material, student participation, tests, follow-up activities [24]. This research got some facts when learning was done by online.

\subsubsection{Pre Instructional Activities}

In observation, it appears that this activity is carried out by explaining the learning objectives of each meeting which are expected to be achieved by students, and apperception (a bridge between old knowledge to new knowledge). Each meeting has certain goals that have been set and leads to one final goal of learning. At this stage, the trainer and administrators convey various information, for example, regarding the preparation for the World Virtual Choir Competition to be participated in. Submitting information can be started from give song material, the entire training schedule, the student recording schedule, learning system, and learning targets. In addition, in the interview it was found that coaches motivate students, even in a pandemic situation, they must remain enthusiastic in positive activities, be able to produce works, and can improve their singing ability. In a pandemic situation, all participants are far apart, so it is also informed that the learning medium used is the Zoom Cloud Meeting. The learning be held at night. The learning was not carried out as a full team, but divided into 2 groups, namely the soprano and tenor totaling 20 students, and the alto and bass totaling 20 students. The grouping is divided based on voice range, soprano is the high voice for women, tenor is the high voice for men. Whereas alto is a low voice for women, bass is a low voice is for men. 


\subsubsection{Material Presentation}

The results of observations and interviews with members of Swara Wadhana Yogyakarta State University Student Choir, show that in delivering the material, the trainer explain the objectives and scope of the material in each meeting. The practice is started by the official by praying and then conveying the rules during the learning. After praying the learning started and the end of the learning was closed with a prayer by the officials. In the interview was found that there were differences in the implementation of direct learning and online learning. In direct learning, on average reading a music score can be done in one meeting because reading music score can be done together by the whole team. But in online learning, the duration for reading music score is longer than direct learning. From the observations, the coach must listen to the students one by one in reading the music score so that takes a long time. It also takes longer because depend on different students' reading ability. The long duration also occurs in the next target (reading lyrics, vocal technique, and interpretation) because the coach has to listen one by one.

In direct learning, the coach gives funny games during the vocalization. According to students, funny games increase their motivation and interest in practicing. However, in online learning, there is no time for games, due to time limitation. At the beginning, it was determined that the duration of each lesson was 3 hours. However, at the first meetings, learning can take almost 3 hours and 30 minutes because there are some students who are not fluent in reading music score.

Based on interviews with students, the rules for the online learning were different from the previous direct learning. Students must be in the online meeting room 10 minutes before learning started. When someone is talking in Zoom Cloud Meeting, for example a coach, the other participants have to mute their microphone. This is done so that the voice is focused on the speaker. Different environments are also the other reason why everyone have to mute their microphone. There are students who live on the side of the road so that sound of vehicles can be heard, there are also students whose houses are located near the rice fields so that there are crickets, etc. In addition, if there are 2 or more people talking together it will cause unclear information provided.

The song being studied is entitled "Fajar dan Senja" by Ken Steven. The song has been shared to students before the rehearsal schedule starts so that it can be learned first. There is different between direct and online learning. Usually, in direct learning the student singing together. But in online learning the students has to sing alone. The reason is the different stability of the internet network. In this condition, the coach demands student self-regulated.

\subsubsection{Student Participation}

The existence of student participation, makes learning more interactive. The activeness of students in participating makes learning not go one way, but can be two ways so make a good communication in learning. Good communication between coach and students supports the continuity of the learning.

From the observations, before the coach checks the students, there are vocalizations/warming up. This vocalization aims to warm voice up so the student can sing better. Students take turns leading the warming up one by one each lesson. Each lesson has certain targets that have been set, including: reading music score, reading the lyrics, vocal technique, song interpretation, and deadlines for taking videos. After that, the students will take turns being called and sing according to the target, for example reading music score, lyrics, or interpretation. Other participants listen to the student who have their turn to sing, as well as listen to the comments given by the coach, so they can learn from the coach's evaluation of the previous student. After the student sings the learning target, the student is also given time to ask the coach what they do not understand, for example: intonation, vocal technique, interpretation and others.

\subsubsection{Test}

Based on observations, the test was carried out after the material presentation was enaugh. After the 10th meeting ended, it was time to do tests for the students. In this section, the final activity is carried out by collecting the final video recordings of the learning results that have been passed so far. When recording a video, the student are guided by a music guide that has been created by the team so that the tempo of all student is the same. The video was then evaluated by the coach in terms of musicality and singing technique. According to the interview with the coach, if there are noise or error in the videos that have been made by students, then the students must repeat them so that the quality of singing and videos is in accordance with the trainer's standards. Facts on the research show that there are some videos that are repeated due to recording noise such as crickets, fan, and vehicle. If the video good, then the video will be mixed by editor by combining all videos into one video.

\subsubsection{Follow-up Activities}

From the observation, the final videos that have been collected are then combined into one video and then packaged becomes more artistic. The editor creates a story board first to help design the flow of the video. After the video is finished, it is sent to the competition organizer. From the results of the interview, it was found that the jury played a very big role in this follow-up activity. Coach and students can see the results of their 
hard work so far and will become an evaluation for future learning.

\subsection{Self-regulated Learning}

Based on a study of various theories about independent learning, Hidayati and Listyani formulated indicators of student learning independence as follows: (1) Independence from others, (2) Self-confidence, (3) Disciplined, (4) Having a sense of responsibility, (5) Behave based on own initiative, and (6) Exercise selfcontrol [22].

\subsubsection{Independence of Others}

One of the learning activities that illustrates this indicator is the ability to read scores without asking other members or trainers for help. The results in the field are unique in this indicator. Even though all of them already have the basic ability to read music scores, it turns out that most students are not sure about their ability to read scores/notation independently. Research show that students majoring in music education are better prepared to read songs. It should be noted that Swara Wadhana Yogyakarta State University Student Choir consists of various majors, not only music, but also other majors such as: science, education, mechatronics, economics, social sciences, and others. Based on interviews, so far, choir learning of Swara Wadhana Choir has been done by singing together. Students who feel that they are not good enough at reading music score hopes to get help from students who are smart in reading music score. Before the pandemic, students were used to learning songs in groups, so when learning was replaced online, some of them felt they were not ready and still dependent on their friends who had high musicality.

\subsubsection{Self-Confidence}

A choir is a collection of a number of students who are grouped according to the type of voice who sing together [24]. Now, learning through Zoom Cloud Meeting requires students to sing alone, not together as in choir learning in general. After making observations, this happened because of the stability of the internet networks of different students, so there was a potential delay if the students sang together. Although singing independently, the results showed that most students had a good level of confidence in singing in front of their coaches and friends. A fiew student felt that they were not confident enough to sing in front of their coach and friends.

\subsubsection{Disciplined}

Discipline is one indicator that determines student self-regulated learning. From the results of observations and interviews, most students always enter the Zoom
Cloud Meeting room before learning begins. Some students joined late due to unstable signals, helped their parents, and blackouts. However, with the condition of online learning, time has become more efficient because they do not need to spend a time to move from home to the practice location.

Attendance at every meeting is also an indicator of disciplined behavior. If someone is unable to join that day for some reason, they can join for another day's meeting with other groups so that they can always follow the process according to the coach's target.

\subsubsection{Responsibility}

Responsibility showed when students have an selfregulated attitude. The students responsibility of their education is to learn. Students who carry out learning activities with personal abilities will try to complete the task well. Research shows that all students be responsible for learning progress by rehearsing the parts of the song that are evaluated by the coach. Responsibility also showed by being involved in the entire process from the start of the meeting to collecting the videos.

\subsubsection{Initiative}

From the observation of Swara Wadhana Yogyakarta State University Student Choir, the initiative behavior itself shown by actively asking the coach when they feel unclear about the coach's explanation both in terms of musicality and vocal techniques. When there was a discussion about costumes, some of them took the initiative to give ideas from their thoughts, as well as during discussions in making dance movements. Students who have good skills in dancing put forward several suggestions of easy moves that match to the song lyrics.

\subsubsection{Self-control}

There are several activities that are concrete actions of implementing self-control indicators such as practicing songs independently out of the training schedule after receiving an evaluation from the coach, listen to evaluations from the coach for other student members, not doing other activities during the learning process. This online activity in choir learning also requires participants to open cameras. This is to anticipate the students from doing other activities during the learning process. In fact, there were some of them who didn't open the camera. In the interview, some revealed that when the camera was opened, the network signal was a bit choked up so they could not hear what the trainer was saying clearly. However, they explained that they did not do other activities as a form of selfcontrol. 


\section{DISCUSSION}

Swara Wadhana UNY Student Choir is a group of Yogyakarta State University students who have an interest in the choir. Choir learning itself is normal like other choir, held together in one place. Until the time when this learning was interrupted for a long time due to the emergence of the COVID-19 pandemic. COVID-19 forces the world of education to make adjustments, replacing classroom learning by implementing health protocols or turning it into online learning. Swara Wadhana Yogyakarta State University Student Choir chose to do online learning, because Yogyakarta State University is one of the universities in Indonesia that minimizes campus activities to prevent the spread of COVID-19. Besides that, with the large number of members, the choir needs a large space when they have to apply physical distancing.

For online learning, Swara Wadhana Yogyakarta State University Student Choir uses Zoom Cloud Meeting as a medium for learning. The innovative technology of Zoom Cloud Meetings allows all participants to see and hear each other at one time, for interactive learning. Learning is carried out by singing alternately individually, so that student self-regulated is needed in this learning.

This was first time for Swara Wadhana Yogyakarta State University Student Choir has participated in a virtual choir competition, so this is also the first time choir learning has been conducted using Zoom Cloud Meeting. Strategies carried out in choir learning according to Uno are pre instructional activities, material presentation, student participation, tests, and follow-up activities. Pre instructional activities which are attractively conveyed will increase student motivation [25]. Since the pandemic, choir learning the "Swara Wadhana" choir at Yogyakarta State University Student Choir only begins with prayer and vocalization, there are no more games to liven up the atmosphere and increase motivation at the beginning of the lesson due to limited time available.

Choir learning through Zoom Cloud Meeting takes more time, but the coach can dig more and know the details of the student, both musicals and vocal techniques. Although there are many obstacles faced by students who are not used to practicing vocals online before, by the times go by, the coach and students can get used to online learning. The coach plays an important role, especially because of separated students from each other due to online training.

Good communication between coach and students certainly supports the continuity of the implementation of learning. The students proactively give themselves to lead vocals at the beginning of the lesson, and if there is something they want to ask, they don't hesitate to find out by asking their coach. The activeness of the students also seen in the discussion, for example discussing the choreo or costumes that would be used for the video recording. This is in line with Yasol's thinking, the learning process will be effective if communication and interaction between teachers and students occurs intensively [26]

The test given at the end of the meeting. This test showed the learning outcomes received by students as well as a description of the feedback from the teacher or speaker. Through tests, teachers or presenters can find out how far students receive learning material. The final activity was in the form of video recording of students singing the songs they had been trained together for 3 weeks. The trainer evaluates one by one so that if there are things that are not suitable, they can fix it. Students asked to retake the video by the coach for example because in their video there are noises such as crickets, fans, and motorcycle. This shows that the different living conditions for students become an obstacle in the recording process.

Follow-up, this activity is a result of learning activities that have be done, but teacher rarely do it[25]. Students get values from video's follow-up by coach. The final videos that have been collected will be combined into one video and packaged becomes more artistic and attractive. After the video is finished, it sent to the competition organizer. Coach and students can see the results of their hard work so far and will become an evaluation for future learning.

Students need the ability of self-regulated for facing independent assignments / studies, open projects, writing thesis, etc. When facing assignments, students are actually faced with a lot of learning resources that may or may not be relevant to the needs and goals of the student. In that conditions, they must have their own initiative and intrinsic motivation, analyze needs and formulate goals, select and implement problem-solving strategies, select relevant sources, and evaluate themselves. Choir learning using Zoom Cloud Meeting makes students have to be more independent, starting from reading music score / notation, which previously could be studied together, now they have to sing independently. It takes confidence and independence from friends. The majority of them are still not able to read the music score independently. Even though they already have a basic reading of music score, it turns out that most of them have not been able to make them reading music score fluently in front of their coach and friends. Goodman and Smart states that independent is defined as behavior whose activities are directed at oneself, not expect other people's direction, and even try and solve problems themselves without asking for help from others [27]. Students who independent in reading music score are students who have a background in music arts education. After they read the music score fluently, they singi songs with the lyric confidently. The results of this opinion are supported by one of the studies conducted by Pratiwi and Laksmiwati which discusses 
Self-Confidence and Learning Independence in Students [28]. Therefore, the higher self-confidence students have, the higher their learning independence, and vice versa.

Choir learning through Zoom Cloud Meeting encourages students to improve their discipline. Selfregulated in online learning occurs on their own initiative. It means that student learning success will be greatly influenced by discipline, creativity, and persistence in studying the materials [26]. Now learning can be done at home, so learning can be started ontime. Usually when they study on campus, students need a time to move from home to campus, which raises delays possibility due to traffic jams. With good discipline, it brings good end results too. These results are supported by research conducted by Sobri and Muldyanto which states that discipline and independent learning simultaneously have a positive effect on student learning outcomes [29].

Beside discipline, students also confirmed agreeing on other indicators, such as having a greater sense of responsibility to learn songs and behaving based on their own initiative. According to Ericson \& Ellett [30] students doing learning acivities as their personal responsibility in the learning process. Students have responsibility for their successful education. This result is supported by the research of Aisyah, Nusantoro and Kurniawan regarding learning responsibility through content mastery services [31]. In this study, it was explained that students who were given content would increase their responsibility. In choir learning, music score is the content given to students.

According to Rusman, independent students must have their own creativity and initiative, and be able to work on their own by referring to the guidance that they get [32]. Students must have self-regulated as good character in learning activity.

Courage to ask is a character that exists in each individual which is shown by confidence and be able to overcome the fear when asking for information and clear answers that has not been understood yet [33]. A good initiative is indicated by the activeness of students to ask coach if they feel unclear about the musical material or vocal technique.

According to Chaplin, self-control is often defined as the ability to organize, guide, regulate and direct forms of behavior that can lead to positive consequences [34]. In the implementation of learning, students show their selfcontrol by practicing songs independently out from the schedule after receiving an evaluation from the coach. Students practice independently so they can sing better in the next meeting. If they don't do it, they may not be ready to sing at the next meeting.

\section{CONCLUSION}

During the pandemic, Swara Wadhana Yogyakarta State University student choir can still carry out online choir learning as well through Zoom Cloud Meeting with learning strategies adjustments, such as pre instructional activities, the material presentation, student participation, tests and follow-up. The positive thing that can be taken through online learning is that the coach can improve student musicality skills and singing techniques individually, even though it takes longer time than direct learning. The role of Zoom Cloud Meeting on student self-regulated showed in good self-confidence, has a disciplined attitude, a sense of responsibility, initiative, and self-control. The self-regulated indicator that has not been fully achieved yet is the independence of other people in reading music score. This constraint can be investigated further in future research.

\section{ACKNOWLEDGMENTS}

I am especially grateful for Prof. Dr. Anik Ghufron for his advice on my study. Special thank to Swara Wadhana Universitas Negeri Yogyakarta Student Choir for being subjects in this research. I thanks to Adventya for help and support me to analysis in this research.

\section{REFERENCES}

[1] E.M. Clarke, E.A. Emerson, Design and synthesis of synchronization skeletons using branching time temporal logic, in: D. Kozen (Eds.), Workshop on Logics of Programs, Lecture Notes in Computer Science, vol. 131, Springer, Berlin, Heidelberg, 1981, pp. 52-71. DOI: https://doi.org/10.1007/BFb0025774

[2] J.P. Queille, J. Sifakis, Specification and verification of concurrent systems in CESAR, in: $M$. Dezani-Ciancaglini and U. Montanari (Eds.), Proceedings of the 5th International Symposium on Programming, Lecture Notes in Computer Science, vol. 137, Springer, Berlin, Heidelberg, 1982, pp. 337-351. DOI: https://doi.org/10.1007/3-54011494-7_22

[3] C. Baier, J-P. Katoen, Principles of Model Checking, MIT Press, 2008.

[4] M. Kwiatkowska, G. Norman, D. Parker, Stochastic model checking, in: M. Bernardo, J. Hillston (Eds.), Proceedings of the Formal Methods for the Design of Computer, Communication and Software Systems: Performance Evaluation (SFM), Springer, Berlin, Heidelberg, 2007, pp. 220-270. DOI: https://doi.org/10.1007/978-3-540-72522-0_6

[5] V. Forejt, M. Kwiatkowska, G. Norman, D. Parker, Automated verification techniques for probabilistic 
systems, in: M. Bernardo, V. Issarny (Eds.), Proceedings of the Formal Methods for Eternal Networked Software Systems (SFM), Springer, Berlin, Heidelberg, 2011, pp. 53-113. DOI: https://doi.org/10.1007/978-3-642-21455-4_3

[6] G.D. Penna, B. Intrigila, I. Melatti, E. Tronci, M.V. Zilli, Bounded probabilistic model checking with the muralpha verifier, in: A.J. Hu, A.K. Martin (Eds.), Proceedings of the Formal Methods in Computer-Aided Design, Springer, Berlin, Heidelberg, 2004, pp. 214-229. DOI: https://doi.org/10.1007/978-3-540-30494-4_16

[7] E. Clarke, O. Grumberg, S. Jha, et al., Counterexample-guided abstraction refinement, in: E.A. Emerson, A.P. Sistla (Eds.), Computer Aided Verification, Springer, Berlin, Heidelberg, 2000, pp. 154-169.

DOI: https://doi.org/10.1007/10722167_15

[8] H. Barringer, R. Kuiper, A. Pnueli, Now you may compose temporal logic specifications, in: Proceedings of the Sixteenth Annual ACM Symposium on the Theory of Computing (STOC), ACM, 1984, pp. 51-63. DOI: https://doi.org/10.1145/800057.808665
[9] A. Pnueli, In transition from global to modular temporal reasoning about programs, in: K.R. Apt (Ed.), Logics and Models of Concurrent Systems, Springer, Berlin, Heidelberg, 1984, pp. 123-144. DOI: https://doi.org/10.1007/978-3-642-82453-1_5

[10] B. Meyer, Applying "Design by Contract", Computer 25(10) (1992) 40-51. DOI: https://doi.org/10.1109/2.161279

[11] S. Bensalem, M. Bogza, A. Legay, T.H. Nguyen, J. Sifakis, R. Yan, Incremental component-based construction and verification using invariants, in: Proceedings of the Conference on Formal Methods in Computer Aided Design (FMCAD), IEEE Press, Piscataway, NJ, 2010, pp. 257-256.

[12] H. Barringer, C.S. Pasareanu, D. Giannakopolou, Proof rules for automated compositional verification through learning, in Proc. of the 2nd International Workshop on Specification and Verification of Component Based Systems, 2003.

[13] M.G. Bobaru, C.S. Pasareanu, D. Giannakopoulou, Automated assume-guarantee reasoning by abstraction refinement, in: A. Gupta, S. Malik (Eds.), Proceedings of the Computer Aided Verification, Springer, Berlin, Heidelberg, 2008, pp. 135-148. DOI: https://doi.org/10.1007/978-3-54070545-1_14 